\title{
Forum
}

\section{Even the rider and a horse are a partnership: a response to Vermeulen \& Sheil}

\author{
Clapperton Mavhunga
}

I situate my reading of Vermeulen \& Sheil (2007) in my research and living experience in the rural villages of Southern Africa. I analyse it as a Western-educated historian of science, technology, environment and society. The opinions I offer are those of someone in the trenches fighting for a dialogue that simultaneously addresses poverty and conservation.

Generally, the intentions and visions of the authors are noble but their framing of and faith in partnership is problematic. I argue that, because their approach does not rigorously interrogate the question of who wants partnership and for what purpose, they fail to escape the charges they level against 'a small group of powerful, external voices' that imposes conservation expertise on local communities. While conceding some agency to local people, Vermeulen \& Sheil are only prepared to go as far as making them 'part of a solution, rather than of the problem, if they are given the opportunity' (my emphasis). I was expecting them to say locals do in fact have solutions to their own problems and that they can actually take a lead in a bottom-up conservation agenda provided the experts are willing to listen and work with them. As it is, the failure to imagine possibilities of a locally innovated conservation package creates the impression that local people are only there to respond to proposals that experts bring, not vice versa.

Clearly, definitions and registers that go beyond animal welfarist and econometric notions are critical when talking about conservationists, conservation, partnership and local communities. Here the authors' problems are compounded by a failure to move beyond literature that underplays how villagers deploy their own practices and attitudes to interpret both their own environments and outsiders with 'strange' ideas about conservation (Fairhead \& Leach, 1996).

The global warming debate shows the danger of romancing partnership. Thus far, global warming seems to be a Western preoccupation, a kind of self-actualization, worded in Western language, with benchmarks and politics Africans have no initiative over and regarding

\footnotetext{
Clapperton Mavhunga University of Michigan, 1029 Tisch Hall, 534 S. State St, MI 48197, USA. E-mail clappertonm@yahoo.com

Received 28 September 2007. Accepted 1 October 2007.
}

which they are only being asked for cooperation. The so-called scientists seek from Africa a global partnership to save the whole planet, to solve symptoms of their own self-interested industrial expansion, which incidentally occurred at Africa's expense. We are told that global warming will affect the Third World most. Politicians, scientists and celebrities have created doomsday dramas that enjoin everyone to prevent the collapse of nature, whilst silencing particular environmental justice questions that created global warming to start with. Villagers are made to sacrifice their well-being, development, environmental heritage rights, and political cultures for an ideology of planetary good whose rationalities are obscure and in fact contrary to their religious beliefs on the origins and fate of Earth.

As I see it, Africa has nothing to gain from joining a Western-driven self-actualization and aesthetic masquerading as conservation partnership. Instead, the world needs a global coalition against poverty and environmental deterioration because one causes the other. That is the answer to global warming. It makes no sense from the African village to save the whole earth from collapsing in centuries when AIDS is decimating people like flies and when savannah anthills are saturated with the graves of Africa's youth. There has to be environmentalism with a conscience when a country has a life expectancy of only 34 years, and $34 \%$ of the population is HIV positive. To say these people are interested in long-term conservation while completely mute on AIDS and poverty is disturbing.

Partnerships for conservation, and against global warming specifically, should not become the new sjambok to whip Africa into line in the same way that the new war on terror has become a pretext for repressive regimes to draft draconian so-called anti-terrorism laws against their own citizens. The United States sees a coalition of the willing; repressive regimes see instruments to silence opposition. Other regimes are already helping themselves to the global warming debate, blaming governanceinduced famine on droughts resulting from this 'scientifically proven' phenomenon.

The unequal power relations that inhere and justify partnership are a legacy of colonialism. Vermeulen \& Sheil's econometric and conservation-centric narrative exhibits a deafening silence on the role of history, race, 
justice, culture and politics in conservation. In southern Africa there are serious policy implications for such silences. First is the post-colonial failure to reassess the validity of Western-centric, aesthetic, and scientific norms of conservation that displaced and criminalized indigenous cultural uses and meanings of wildlife (Carruthers, 1995). The dominance of scholarship that focuses on the present and future has prevented conservation discourse from tapping into a more nuanced historical, literary and cultural understanding of human-environment relations. Second, local people are being marginalized from protected areas through the overpricing and packaging of nature according to values irrelevant to them. This Western-centric aesthetic vision of nature is not shared by everybody. Finally, while rich outsiders have access to investment inside the parks, villagers do not. Meanwhile, even when villagers see an elephant or lion ravishing their crops or livestock if they do so much as injure it they will go to jail for poaching. If they lodge compensation claims, the redress process takes forever (IUCN \& TPARI, 2005). The authors seem to be approaching partnership from the direction of conservancies and those that worship ecosystems. From the village, such ideals mean nothing and are irrelevant to the hard struggle that is life.

The authors define successful partnership as beginning from joint planning but where is the idea conceived? From the village, Western-centric experts seem to already have it all figured out by the time they come to villagers seeking space and cooperation for cooking their already prepared menu (Tapela et al., 2007). Conservationists complain that local people are difficult to work with and that conservation is a complex issue beyond the lay person's comprehension and is better left to the experts. They say social research is too detailed: 'if social researchers really want us to consider their findings and turn them into policy', one conservation biologist said in 2005, 'they must simplify their 500-page reports into 1-2 page précis' (IUCN \& TPARI, 2005). This discovery was shocking but illustrative of the difficulty of partnership between Western-defined experts and Western-designated laymen.

Partnership is simply not enough: we need a new democracy of knowledge. It is time for the idea and practice of conservation to embrace the spiritual, cultural, social, political and even technological aspirations of local people. The register of ecosystems should yield to the language of culture, for even those that make scientific claims of global warming are doing so to save the purpose of human existence. We need to open up the space for environmental dialogue beyond the disciplines of ecology, biology, sociology, economics and anthropology to new realms of expertise that historicize and forecast. This requires multidisciplinary collaboration to understand societal values about specifically situated environments, rather than one-size-fits-all initiatives that ignore local histories and aspirations.

Partnership for conservation is passé; let us move on to a renaissance that tackles both poverty and environment and makes conservation an opportunity for eradicating poverty. We need first to ask ourselves: how have local villagers survived despite the odds stacked against them? By answering this question conservationists could pretend for once that they are clueless about the role of nature in non-western societies so that they would be humble enough to go in as blank slates and be more receptive to local people's views. They could find out what the villagers see as the problems and take on board how they imagine they could be solved. Thereafter, they would return and see how they could weave their own scientific ideas and money into locally generated strategies. That is how we can avoid partnerships being like that between a rider and a horse, where some shoulder the burden whilst others enjoy the scenery. The conservationist should not become to locals what the Native Commissioner was to the natives during the colonial era. Conservationists underestimate local intellect at their own loss. Villagers can play along, eat the donor money, and when the usual 5-year project winds up, carry on with their lives as if nothing had happened.

\section{References}

Carruthers, J. (1995) The Kruger National Park: A Social and Political History. Natal University Press, Pietermaritzburg, South Africa.

Fairhead, J. \& Leach, M. (1996) Misreading the African Landscape: Society and Ecology in a Forest Savanna Mosaic. Cambridge University Press, Cambridge, UK.

IUCN \& TPARI (2005) Indaba on Social Research and Protected Areas: Towards Equitable Best Practice and Community Empowerment. 10-13 April 2005, Kruger National Park, South Africa.

Mavhunga, C. \& Dressler, W. (2007) On the local community: the language of disengagement? Conservation and Society, 5, 44-59.

Tapela, B., Maluleke, M. \& Mavhunga, C. (2007) New architecture, old agendas: perspectives on social research in rural communities neighbouring the Kruger National Park. Conservation and Society, 5, 60-87.

Vermeulen, S. \& Sheil, D. (2007) Partnerships for tropical conservation. Oryx, 41, 434-440. 